\title{
Communication \\ Development of a Novel Enzymatic Pretreatment for Improving the Digestibility of Protein in Feather Meal
}

\author{
Guillaume Pfeuti *(i), Vernon Osborne, Anna K. Shoveller $($, Eric H. Ignatz® \\ and Dominique P. Bureau \\ Department of Animal Biosciences, University of Guelph, Guelph, ON N1G 2W1, Canada; \\ vosborne@uoguelph.ca (V.O.); ashovell@uoguelph.ca (A.K.S.); ehignatz@mun.ca (E.H.I.); \\ dbureau@uoguelph.ca (D.P.B.) \\ * Correspondence: guillaume.pfeuti@gmail.com
}

Received: 30 August 2019; Accepted: 1 October 2019; Published: 7 October 2019

check for updates

\begin{abstract}
This study describes the process of developing an enzymatic pretreatment to improve the nutritional value of feather meal (FeM). In a first experiment, a full factorial design was used to examine the effects of various incubation conditions on the solubilization of nitrogen in FeM. We incubated FeM for $3 \mathrm{~h}$ with various levels of a commercial alkaline serine protease (Savinase ${ }^{\circledR}$ $16 \mathrm{~L})$, sodium sulphite $\left(\mathrm{Na}_{2} \mathrm{SO}_{3}\right)$, and digestion buffer. A Savinase ${ }^{\circledR} 16 \mathrm{~L}$ level of $3 \%(\% \mathrm{FeM} v / w)$, $\mathrm{Na}_{2} \mathrm{SO}_{3}$ level of $3 \%(\% \mathrm{FeM} w / w)$, and digestion buffer level of $500 \%(\% \mathrm{FeM} w / w)$ were identified as the optimal conditions. Under these optimal conditions, $45 \%$ of the nitrogen in FeM was solubilized. In a second experiment, we evaluated the effect of more economically sustainable incubation conditions on the in vitro digestibility of protein (pepsin- $\mathrm{HCl}$ digestibility and multistep protein evaluation) in FeM. Two FeMs were incubated with $0.5 \%$ Savinase ${ }^{\circledR} 16 \mathrm{~L}(\% \mathrm{FeM} v / w), 2 \% \mathrm{Na}_{2} \mathrm{SO}_{3}(\% \mathrm{FeM} w / w)$, and $200 \%$ buffer ( $\% \mathrm{FeM} w / w)$ for $24 \mathrm{~h}$. The pretreatment improved pepsin- $\mathrm{HCl}$ digestibility by $7-16 \%$ and the total tract degradable protein content by $14-50 \%$. Accordingly, this novel pretreatment could be applied in the animal feed industry to improve the nutritional value of FeM.
\end{abstract}

Keywords: digestibility; enzymatic hydrolysis; feather meal; keratin; protein

\section{Introduction}

Feather meal (FeM) is a cost-effective and high-protein (75-85\%) feed ingredient created through the steam hydrolysis of keratinous coproducts generated by the meat industry [1,2]. Such keratinous waste consists mostly of poultry feathers, but also includes hog hair and hooves.

Raw keratin is virtually indigestible due to the cross-linking of disulphide bridges [3]. To make raw keratin digestible, the rendering industry uses steam hydrolysis along with high pressure to break down these chemical bonds [3]. Once hydrolyzed, the keratinaceous material is dried, cooled, and milled to produce the free-flowing palatable meal known as FeM.

Despite its interesting characteristics (high in protein and cost-effective), FeM is notorious amongst feed industry stakeholders for its variability in nutritional value [1,2]. Variability in FeM protein digestibility has been associated with the use of diverse raw materials and commercial processing systems under various processing conditions (pressure, temperature, time) by renderers [3].

In previous studies, we have demonstrated that incubating FeM with $0.5 \%$ Savinase ${ }^{\circledR} 16 \mathrm{~L}(\% \mathrm{FeM}$ $v / w), 2 \% \mathrm{Na}_{2} \mathrm{SO}_{3}(\% \mathrm{FeM} w / w)$, and $200 \%$ buffer $(\% \mathrm{FeM} w / w)$ for $24 \mathrm{~h}$ significantly $(p<0.005)$ improved the digestibility and bioavailability in FeM fed to rainbow trout (Oncorhynchus mykiss) [1,2]. Moreover, FT-Raman analyses suggested that this pretreatment facilitated the digestibility of protein in FeM by reducing the concentration and conformational stability of disulphide bonds in this feed ingredient [2]. 
The development of this process was based on other studies demonstrating that raw keratin could be efficiently hydrolyzed using the protease Savinase ${ }^{\circledR} 16 \mathrm{~L}$ along with a reducing agent $[4,5]$. Furthermore, additional studies proposed that disrupting disulphide bonds caused reducing agents to unfold the protein structure of keratin, thereby exposing peptide bonds to proteases, which subsequently cleaved protein into peptides and amino acids making keratin soluble $[5,6]$.

Given the success of this pretreatment for improving amino acid utilization in FeM fed to rainbow trout, it was considered valuable to share the steps involved in its development. Through a first experiment, the effects of incubation buffer level, Savinase ${ }^{\circledR} 16 \mathrm{~L}$ level, and sodium sulphite level on the hydrolysis of FeM were assessed. Subsequently, incubation conditions were selected and their effect on the in vitro digestibility of protein in two FeMs was evaluated.

\section{Materials and Methods}

\subsection{Experiment 1}

\subsubsection{Feather Meal and Reagents}

The FeM used in this trial consisted of a mixture of steam-hydrolyzed hog hair and broiler feathers (approximately 15\% and 85\%, respectively). This FeM was from the same batch as FeM1 used in Pfeuti et al. [2]. The chemical composition of this FeM (FeM1) is described in Table 1. Sodium sulphite and commercial protease Savinase ${ }^{\circledR}$ 16L (product number S0505 and P3111, respectively) were purchased from Sigma-Aldrich (Sigma-Aldrich Inc., MD, USA). Savinase ${ }^{\circledR} 16 \mathrm{~L}$ is an alkaline serine protease from Bacillus sp. with an activity of 16,000 novo protease units.

Table 1. Proximate composition analysis and gross energy and amino acid profiles of feather meals, adapted from Pfeuti et al. [2].

\begin{tabular}{|c|c|c|c|c|}
\hline & \multicolumn{4}{|c|}{ Feather Meals } \\
\hline & FeM1 & PTFeM1 & FeM2 & PTFeM2 \\
\hline \multicolumn{5}{|l|}{ Proximate composition (as is) } \\
\hline Dry matter (g/kg) & 934 & 933 & 866 & 931 \\
\hline Crude protein $(\mathrm{g} / \mathrm{kg})$ & 819 & 803 & 763 & 817 \\
\hline Lipid $(\mathrm{g} / \mathrm{kg})$ & 83 & 79 & 65 & 65 \\
\hline Total carbohydrates $(\mathrm{g} / \mathrm{kg})^{1}$ & 13 & 13 & 15 & 6 \\
\hline $\operatorname{Ash}(\mathrm{g} / \mathrm{kg})$ & 19 & 38 & 23 & 43 \\
\hline Gross energy $(\mathrm{kJ} / \mathrm{g})^{1}$ & 22.6 & 22.1 & 20.7 & 21.8 \\
\hline \multicolumn{5}{|l|}{ Essential amino acids ( $\mathrm{g} / \mathrm{kg}$ as is) } \\
\hline Arginine & 59 & 57 & 57 & 61 \\
\hline Histidine & 6 & 6 & 7 & 8 \\
\hline Isoleucine & 40 & 39 & 35 & 38 \\
\hline Leucine & 67 & 65 & 62 & 66 \\
\hline Lysine & 18 & 18 & 22 & 23 \\
\hline Methionine & 5 & 5 & 6 & 6 \\
\hline Phenylalanine & 40 & 39 & 34 & 36 \\
\hline Threonine & 39 & 38 & 38 & 40 \\
\hline Valine & 60 & 58 & 51 & 56 \\
\hline \multicolumn{5}{|l|}{ Non-essential amino acids ( $\mathrm{g} / \mathrm{kg}$ as is) } \\
\hline Alanine & 38 & 37 & 36 & 38 \\
\hline Aspartic acid & 56 & 55 & 55 & 58 \\
\hline Cyst(e)ine & 35 & 36 & 41 & 43 \\
\hline Glutamic acid & 92 & 90 & 97 & 101 \\
\hline Glycine & 65 & 63 & 58 & 62 \\
\hline Proline & 83 & 78 & 68 & 73 \\
\hline Serine & 93 & 88 & 81 & 84 \\
\hline
\end{tabular}


Table 1. Cont.

\begin{tabular}{ccccc}
\hline & \multicolumn{4}{c}{ Feather Meals } \\
\cline { 2 - 5 } & FeM1 & PTFeM1 & FeM2 & PTFeM2 \\
\hline Cross-linked amino acids $(\mathrm{g} / \mathrm{kg}$ as is) & & & & \\
Lanthionine & 31.8 & 31.7 & 25.5 & 28 \\
DL-Lysinoalanine & 1.6 & 1.5 & 0.6 & 0.7 \\
B-aminoalanine & 1.4 & 1.3 & 0.5 & 0.6 \\
\hline
\end{tabular}

Note: FeM1, feather meal 1; PTFeM1, pretreated feather meal 1; FeM2, feather meal 2; PTFeM2, pretreated feather meal $2 ;{ }^{1}$ Calculated values.

\subsubsection{Experimental Design and Procedures}

The effect of three factors on the degree of hydrolysis $(\mathrm{DH})$ of FeM1 were evaluated through a full factorial design: (1) Savinase ${ }^{\circledR} 16 \mathrm{~L}$ loading at $0 \%, 1 \%, 2 \%$, and $3 \%$ of FeM $(v / w)$, (2) sodium sulphite level at $0 \%, 1.5 \%, 3 \%$ of FeM $(w / w)$, and (3) digestion buffer level at $200 \%, 350 \%$, and $500 \%$ of FeM $(w / w)$. A total of 36 experiments were conducted in triplicate at all points in a fully randomized design. The levels for each variable were selected based on preliminary work and previous studies $[5,7,8]$.

FeM samples $(20 \mathrm{~g})$ were mixed with various levels of Savinase ${ }^{\circledR} 16 \mathrm{~L}(0 \%, 1 \%, 2 \%$, or $3 \%$ FeM $(v / w)$, sodium sulphite $(0 \%, 1.5 \%$, or $3 \% \mathrm{FeM}(w / w)$, and digestion buffer $(200 \%, 350 \%$, or $500 \%$ FeM $(w / w)$ in $250 \mathrm{~mL}$ plastic bottles with screw caps (Sorvall ${ }^{\circledR}$ Instruments, Wilmington, DE, USA). The buffer was prepared by mixing distilled water with tris $(0.01 \mathrm{M})$ and sodium azide $(0.05 \% \mathrm{w} / \mathrm{v})$ according to Coll et al. [9]. The $\mathrm{pH}$ of the digestion buffer was adjusted to the optimum level recommended by the enzyme manufacturer ( $\mathrm{pH} 10$ ) by adding $0.2 \mathrm{~N} \mathrm{NaOH}$. Hydrolysis was initiated prior to incubation by adding Savinase ${ }^{\circledR} 16 \mathrm{~L}$ to the mixtures. Each incubation was performed for $3 \mathrm{~h}$ in a temperature-controlled water bath (Haake SWB25, Karlsruhe, Germany) with constant agitation $(110 \mathrm{rpm})$ and temperature adjusted to the optimum temperature for the enzyme $\left(55^{\circ} \mathrm{C}\right)$. Each treatment was performed in triplicate.

The treatments were terminated by adding one volume of $20 \%$ trichloroacetic acid (TCA) solution, which was followed by centrifugation at $4000 \mathrm{rpm}$ for $10 \mathrm{~min}$ (Eppendorf $5810 \mathrm{R}$ equipped with an A-4-62 rotor, Hamburg, Germany) to collect a 10\% TCA-soluble nitrogen solution as the supernatant. The supernatant was then transferred into a separate container and stored overnight at $4{ }^{\circ} \mathrm{C}$ until nitrogen analysis.

\subsubsection{Laboratory Analyses}

The FeM and 10\% TCA-soluble supernatants were analyzed for nitrogen via the macro-Kjeldahl method [10] using a Kjeltec protein analyzer (Model \#8200, Tecator, Hoganas, Sweden). Distilled solutions were titrated using $0.1 \mathrm{M}$ hydrochloric acid. Nitrogen analyses were performed twice for every incubation sample to increase confidence in the results.

\subsubsection{Calculations and Statistical Analyses}

The DH was calculated as per the methodology described by Hoyle and Merrit [11] using:

$$
\mathrm{DH}=\frac{\text { Total TCA-soluble nitrogen in supernatant }}{\text { Total nitrogen in } 20 \mathrm{~g} \text { of feather meal }} \times 100
$$

JMP $^{\circledR}$, V12.2.0 (SAS Institute Inc., Cary, NC, 1989-2007) was used to analyze the full factorial design. The linear and quadratic effects of the three variables (buffer, Savinase ${ }^{\circledR} 16 \mathrm{~L}$, and sodium sulphite) and their interactions on the degree of hydrolysis were calculated. The significance of these variables were assessed by analysis of variance (ANOVA) and considered significant at $p<0.05$. The experimental data were fitted using a second-order polynomial equation to describe the main effects in terms of linear, quadratic, and interactions: 


$$
Y=b_{0}+\sum_{i=1}^{3} b_{i} X_{i}+\sum_{i=1}^{3} b_{i} X_{i}^{2}+\sum_{i=1}^{2} \sum_{j=i+1}^{3} b_{i j} X_{i} X_{j}
$$

where $Y$ is the degree of hydrolysis, $X_{i}$ is the independent variables, and $b_{\mathrm{i}}$ is the regression coefficients. The fit of the second-order equations were evaluated by the determination of R-squared coefficient and adjusted R-squared coefficient.

The DH of the 36 combinations were grouped per inclusion level for each factor (buffer, protease, and sodium sulphite) and compared by a one-way ANOVA followed by Tukey's HSD (honestly significant difference), with differences being considered significant at $p<0.05$. Digestion buffer, enzyme, and sodium sulphite levels were regressed against $\mathrm{DH}$ to determine the linear and quadratic effect of the variables on $\mathrm{DH}$, which were considered significant at $p<0.05$.

\subsection{Experiment 2}

\subsubsection{Feather Meal Samples and Reagents}

The FeMs (FeM1 and FeM2) used in the study were obtained from two different local rendering plants and were sourced from the same batch used in Pfeuti et al. [2]. Both FeMs (FeM1 and FeM2) were composed of approximately $15 \%$ hog hair and $85 \%$ chicken feathers (see Table 1 for their chemical compositions). Reagents were obtained from the same sources as in Experiment 1.

\subsubsection{Enzymatic Pretreatment of Feather Meal}

The two FeMs were pretreated as described by Pfeuti et al. [2]. Briefly, one kilogram batches of FeM were mixed with $2 \mathrm{~L}$ of digestion buffer $(200 \%$ digestion buffer, $\% \mathrm{FeM} w / w)$ and $2 \%$ sodium sulphite (\%FeM $w / w)$ in 3 litre plastic containers (B350-Urisafe ${ }^{\circledR}$, Simport, Saint-Mathieu-de-Beloeil, $\mathrm{QC}$, Canada). The $\mathrm{pH}$ of the mixture was adjusted to 10 using $0.2 \mathrm{M} \mathrm{NaOH}$. The hydrolysis process was performed in a shaking incubator (G25, New Brunswick Scientific, Enfield, CT, USA) set at $55^{\circ} \mathrm{C}$ and $200 \mathrm{rpm}$. Enzymatic hydrolysis was initiated by adding $0.5 \%$ of Savinase ${ }^{\circledR} 16 \mathrm{~L}(\% \mathrm{FeM} v / w)$ (Sigma-Aldrich Inc., MD, USA). After $24 \mathrm{~h}$, the enzyme was deactivated by heating the mixtures to $90{ }^{\circ} \mathrm{C}$ for $5 \mathrm{~min}$ in a microwave oven. The two pretreated FeMs (PTFeMs) were then lyophilized and milled. The PTFeMs resulting from the pretreatment of FeM1 and FeM2 were identified as PTFeM1 and PTFeM2, respectively (see Table 1 for their chemical compositions).

\subsubsection{In Vitro Digestibility of Feather Meal}

FeM and PTFeM samples were sent to Cumberland Valley Analytical Services (Madison, WI, USA) to assess in vitro pepsin- $\mathrm{HCl}$ digestibility according to (1) AOAC Official Method 971.09 [10] and (2) multistep protein evaluation (MSPE) according to Ross et al. [12].

\section{Results and Discussion}

\subsection{Experiment 1}

The present study is, to the authors' knowledge, the first published study to investigate the dynamics of various combinations of digestion buffer, protease enzyme, and sodium sulphite levels on the enzymatic hydrolysis of FeM. The responses of DH to Savinase ${ }^{\circledR}$ 16L level (X1), sodium sulphite level (X2), and digestion buffer level (X3) on the DH are reported in Table 2. Maximum DH (45.1\%) was achieved with $3 \%$ protease $(\% \mathrm{FeM} w / w), 3 \%$ sodium sulphite $(\% \mathrm{FeM} w / w)$, and $500 \%$ digestion buffer $(\% \mathrm{FeM} w / w)$. In this research effort, we observed that FeM could be successfully hydrolyzed when incubated with Savinase ${ }^{\circledR} 16 \mathrm{~L}$ and sodium sulphite. This indicates that the method developed by Eslahi et al. [5] — who extracted keratin from wool and feathers using an enzymatic treatment along with a reducing agent-was also applicable to hydrolyzing FeM. 
Table 2. Experimental design and response to the three independent variables.

\begin{tabular}{|c|c|c|c|c|c|c|}
\hline \multirow{2}{*}{$\begin{array}{c}\text { Run } \\
\text { Number }\end{array}$} & \multicolumn{3}{|c|}{ Independent Variables } & \multirow{2}{*}{\multicolumn{3}{|c|}{ Degree of Hydrolysis (\%) ${ }^{4}$}} \\
\hline & $X 1^{1}$ & $X 2^{2}$ & $X 3^{3}$ & & & \\
\hline 1 & 0 & 0 & 200 & 9.3 & \pm & 0.14 \\
\hline 2 & 1 & 0 & 200 & 16.1 & \pm & 0.71 \\
\hline 3 & 2 & 0 & 200 & 17.3 & \pm & 0.48 \\
\hline 4 & 3 & 0 & 200 & 18.5 & \pm & 0.42 \\
\hline 5 & 0 & 1.5 & 200 & 9.7 & \pm & 0.33 \\
\hline 6 & 1 & 1.5 & 200 & 22.4 & \pm & 1.09 \\
\hline 7 & 2 & 1.5 & 200 & 25.7 & \pm & 0.80 \\
\hline 8 & 3 & 1.5 & 200 & 27.1 & \pm & 0.31 \\
\hline 9 & 0 & 3 & 200 & 9.8 & \pm & 0.51 \\
\hline 10 & 1 & 3 & 200 & 27.4 & \pm & 1.32 \\
\hline 11 & 2 & 3 & 200 & 31.2 & \pm & 0.37 \\
\hline 12 & 3 & 3 & 200 & 32.9 & \pm & 0.60 \\
\hline 13 & 0 & 0 & 350 & 9.4 & \pm & 0.30 \\
\hline 14 & 1 & 0 & 350 & 17.0 & \pm & 0.22 \\
\hline 15 & 2 & 0 & 350 & 18.7 & \pm & 0.13 \\
\hline 16 & 3 & 0 & 350 & 21.2 & \pm & 0.59 \\
\hline 17 & 0 & 1.5 & 350 & 10.2 & \pm & 0.31 \\
\hline 18 & 1 & 1.5 & 350 & 27.4 & \pm & 0.57 \\
\hline 19 & 2 & 1.5 & 350 & 30.7 & \pm & 0.68 \\
\hline 20 & 3 & 1.5 & 350 & 31.8 & \pm & 1.56 \\
\hline 21 & 0 & 3 & 350 & 10.3 & \pm & 0.38 \\
\hline 22 & 1 & 3 & 350 & 36.2 & \pm & 0.39 \\
\hline 23 & 2 & 3 & 350 & 40.1 & \pm & 0.25 \\
\hline 24 & 3 & 3 & 350 & 43.5 & \pm & 1.62 \\
\hline 25 & 0 & 0 & 500 & 10.0 & \pm & 0.42 \\
\hline 26 & 1 & 0 & 500 & 18.6 & \pm & 0.06 \\
\hline 27 & 2 & 0 & 500 & 20.4 & \pm & 0.76 \\
\hline 28 & 3 & 0 & 500 & 22.0 & \pm & 0.82 \\
\hline 29 & 0 & 1.5 & 500 & 10.2 & \pm & 0.08 \\
\hline 30 & 1 & 1.5 & 500 & 28.8 & \pm & 0.79 \\
\hline 31 & 2 & 1.5 & 500 & 30.5 & \pm & 0.76 \\
\hline 32 & 3 & 1.5 & 500 & 33.2 & \pm & 0.37 \\
\hline 33 & 0 & 3 & 500 & 10.7 & \pm & 0.28 \\
\hline 34 & 1 & 3 & 500 & 38.3 & \pm & 1.85 \\
\hline 35 & 2 & 3 & 500 & 39.3 & \pm & 1.68 \\
\hline 36 & 3 & 3 & 500 & 45.1 & \pm & 1.62 \\
\hline
\end{tabular}

${ }^{1} \mathrm{X} 1=$ Savinase ${ }^{\circledR} 16 \mathrm{~L}$ level $(\% \mathrm{FeM} v / w) ;{ }^{2} \mathrm{X} 2=$ sodium sulphite level $(\% \mathrm{FeM} w / w) ;{ }^{3} \mathrm{X} 3=$ digestion buffer $(\% \mathrm{FeM}$ $w / w) ;{ }^{4}$ data are means $(\mathrm{n}=3) \pm$ standard deviation.

\subsubsection{Effect of Variables, and Their Interaction, on Degree of Hydrolysis}

The analysis of variance for DH is shown in Table 3. The linear effect of Savinase ${ }^{\circledR} 16 \mathrm{~L}$ level and of sodium sulphite level along with the interaction effect between the two were substantially higher than other effects $(p<0.0001)$, establishing that these are the most significant factors affecting the DH. The quadratic effects of both digestion buffer level and Savinase ${ }^{\circledR} 16 \mathrm{~L}$ level presented a very high effect $(p<0.001)$ in the model. The quadratic effect of the sodium sulphite level did not have a significant $(p<0.05)$ effect in the model. The analysis of variance established that the model is statistically valid with $p<0.001$.

The DH has been modeled by keeping significant factors $(p<0.05)$ in the following equation:

$$
\begin{aligned}
& \mathrm{DH}=1.88+(11.44 \times \mathrm{X} 1)-(0.50 \times \mathrm{X} 2)+\left(4.77 \times 10^{-2} \times \mathrm{X} 3\right)-\left(3.37 \times X 1^{2}\right)-\left(7.10 \times 10^{-5} \times X 3^{2}\right) \\
& +(1.96 \times X 1 \times X 2)+\left(6.16 \times 10^{-3} \times X 1 \times X 3\right)+\left(6.21 \times 10^{-3} \times \mathrm{X} 2 \times X 3\right)
\end{aligned}
$$


The polynomial prediction equation for DH had a $r^{2}=0.941$, an adjusted $r^{2}=0.936$, and a $p<0.0001$. The adjusted $r^{2}$ implies that $93.6 \%$ of the behaviour variation of $\mathrm{DH}$ can be explained by the fitted model.

Table 3. ANOVA table of degree of hydrolysis (DH) as affected by Savinase ${ }^{\circledR} 16 \mathrm{~L}$ level, sodium sulphite level, and digestion buffer level during response experiment.

\begin{tabular}{ccccc}
\hline Source & DF & Sum of Squares & F Ratio & $p$-Value \\
\hline Model & 9 & $11,718.33$ & 176.09 & $<0.0001$ \\
$X 1$ : Savinase ${ }^{\circledR}$ 16L Level & 1 & 5565.90 & 752.75 & $<0.0001$ \\
$X 2$ : Sodium Sulphite Level & 1 & 3459.98 & 467.94 & $<0.0001$ \\
X3: Digestion Buffer Level & 1 & 443.33 & 59.96 & $<0.0001$ \\
$X 1^{2}$ & 1 & 780.70 & 105.58 & $<0.0001$ \\
$X 2^{2}$ & 1 & 6.48 & 0.88 & 0.3515 \\
$X 3^{2}$ & 1 & 61.31 & 8.29 & 0.0049 \\
$X 1^{*} X 2$ & 1 & 1230.06 & 166.36 & $<0.0001$ \\
$X 1^{*} X 3$ & 1 & 76.93 & 10.40 & 0.0017 \\
$X 2^{*} X 3$ & 1 & 93.64 & 12.66 & 0.0006 \\
Residual $_{\text {Correlation total }}$ & 98 & 724.617 & 7.39 & \\
\hline$X 11.44 \times X 1)+(0.20 \times X 2)+\left(4.77 \times 10^{-2} \times X 3\right)-\left(3.37 \times X 1^{2}\right)-\left(0.23 \times X 2^{2}\right)-\left(7.10 \times 10^{-5} \times X 3^{2}\right)+$
\end{tabular}

The analysis of the model revealed that the optimal parameters required to obtain the highest $\mathrm{DH}$ $(45.1 \%)$ were: $3 \%$ of protease $(\% \mathrm{FeM} w / w), 3 \%$ of sodium sulphite $(\% \mathrm{FeM} w / w)$, and $500 \%$ of digestion buffer $(\% \mathrm{FeM} w / w)$. This combination of parameters in the model is identical to the one promoting the highest experimental responses.

The optimal incubation parameters represent the highest inclusion levels tested for all three factors. Notably, from an economic standpoint, the level of added protease and digestion buffer represent decisive factors affecting the cost of the enzymatic pretreatment process [13,14]. Indeed, protease cost is a critical consideration in commercial operations; therefore, its use should be minimized [15]. Moreover, increased digestion buffer inclusion involves greater thermo-energetic input costs for drying the sludge into a powdered form that can be incorporated into feed formulations [16]. Consequently, we decided to select a lower inclusion level for each factor to develop a more cost-effective pretreatment by using a simplistic, but systematic approach. To do so, we performed Tukey's HSD analyses for each factor and determined the linear and quadratic effects of the factors on the degree of hydrolysis (Table 4).

Table 4. Tukey's honestly significant difference (HSD) analyses and the linear and quadratic effects of buffer, Savinase ${ }^{\circledR} 16 \mathrm{~L}$, and $\mathrm{Na}_{2} \mathrm{SO}_{3}$ levels on the degree of hydrolysis.

\begin{tabular}{lccc}
\hline \multirow{2}{*}{ Statistical Parameter } & \multicolumn{3}{c}{ Independent Variables } \\
\cline { 2 - 4 } & $\boldsymbol{X} \mathbf{1}^{\mathbf{1}}$ & $\boldsymbol{X} \mathbf{2}^{\mathbf{2}}$ & $\boldsymbol{X} \mathbf{3}^{\mathbf{3}}$ \\
\hline Tukey's HSD (Inclusion Level; $\mathrm{DH}^{4}$ ) & & \\
& $200 \% ; 20.6^{\mathrm{b}}$ & $0 \% ; 10.0^{\mathrm{c}}$ & $0 \% ; 16.5^{\mathrm{a}}$ \\
& $350 \% ; 24.7^{\mathrm{a}}$ & $1 \% ; 25.0^{\mathrm{b}}$ & $1.5 \% ; 24.0^{\mathrm{b}}$ \\
& $500 \% ; 25.6^{\mathrm{a}}$ & $2 \% ; 28.2^{\mathrm{ab}}$ & $3 \% ; 30.4^{\mathrm{c}}$ \\
& & $3 \% ; 30.6^{\mathrm{a}}$ & \\
Linear Effect $\left(p\right.$-value; $\left.r^{2}\right)$ & $0.0504 ; 0.04$ & $<0.0001 ; 0.45$ & $<0.0001 ; 0.45$ \\
Quadratic Effect $\left(p\right.$-value; $\left.r^{2}\right)$ & & & \\
& $0.0504 ; 0.04$ & $<0.0001 ; 0.55$ & $<0.0001 ; 0.28$
\end{tabular}

${ }^{1} \mathrm{X} 1=\overline{\text { Savinase }^{\circledR}} 16 \mathrm{~L}$ level $(\% \mathrm{FeM} v / w) ;{ }^{2} \mathrm{X} 2=$ sodium sulphite level $(\% \mathrm{FeM} w / w) ;{ }^{3} \mathrm{X} 3=$ digestion buffer level $(\% \mathrm{FeM} w / w) ;{ }^{4}$ data are means $(X 1, \mathrm{n}=12 ; X 2, \mathrm{n}=9 ; X 3, \mathrm{n}=12)$; values followed by a common superscript letter are not significantly different $(p>0.05)$. 


\subsubsection{Selecting Savinase ${ }^{\circledR} 16 \mathrm{~L}$ level}

The level of Savinase ${ }^{\circledR} 16 \mathrm{~L}$ had significant positive linear $\left(p<0.0001 ; r^{2}=0.45\right)$ and quadratic $\left(p<0.0001 ; r^{2}=0.45\right)$ effects on DH (Table 4). Normah et al. [17] reported a positive increase in DH values based on enzyme:substrate (E:S) ratio studies on the hydrolysis of proteins from fish by-products with the commercial enzyme Alcalase ${ }^{\circledR}$. They explained that this phenomenon was due to greater enzyme concentrations providing more available active sites to hydrolyze the substrate. However, there is a stronger quadratic than linear relationship between Savinase ${ }^{\circledR} 16 \mathrm{~L}$ concentration and DH. Furthermore, Normah et al. [17] also stated that DH should not be expected to rise linearly with increased protease level since proteolytic activity is limited by the availability of susceptible peptide bonds to hydrolysis, which is consistent with the results of the present study.

The DH increased most when increasing Savinase ${ }^{\circledR} 16 \mathrm{~L}$ level from $0 \%$ to $1 \%(\% \mathrm{FeM} v / w)$, and then stopped increasing significantly with each protease increase of $1 \%(\% \mathrm{FeM} w / w)$, which can be seen in Table 4. This observation is also in agreement with the study of Normah et al. [17], who reported no significant increase in $\mathrm{DH}$ above an enzyme substrate ratio (E:S) of $2 \%$. Moreover, data from Normah et al. [17] showed that an E:S of $0.5 \%$ has $85 \%$ to $90 \%$ of the efficacy of an E:S of $1 \%$ on DH after $3 \mathrm{~h}$ of incubation.

Moreover, studies investigating the kinetics of fish by-product hydrolysis showed that equivalent DH levels were reached at low enzyme levels for prolonged incubation times and at high protease inclusion for short hydrolysis periods $[15,18]$. Therefore, it was considered that $0.5 \%$ Savinase ${ }^{\circledR} 16 \mathrm{~L}$ $(\% \mathrm{FeM} v / w)$ may be sufficient for our application if the incubation period was extended.

\subsubsection{Selecting Sodium Sulphite Level}

Significant positive linear $(p<0.0001)$ and quadratic $(p<0.0001)$ effects on DH from sodium sulphite were observed (Table 4$)$. DH significantly increased $(p<0.05)$ with each increase of sodium sulphite (Table 4). However, the increase of DH was greater when increasing sodium sulphite from $0 \%$ to $1.5 \%(\% \mathrm{FeM} w / w)$ than from $1.5 \%$ to $3 \%(\% \mathrm{FeM} w / w)$.

Interestingly, the addition of $\mathrm{Na}_{2} \mathrm{SO}_{3}$ at any given Savinase ${ }^{\circledR} 16 \mathrm{~L}$ level enhanced the hydrolytic capacity of the protease more than an increase in enzyme loading alone. For instance, at $1 \%$ Savinase ${ }^{\circledR}$ $16 \mathrm{~L}(\% \mathrm{FeM} v / w), 0 \% \mathrm{Na}_{2} \mathrm{SO}_{3}(\% \mathrm{FeM} w / w)$, and $350 \%$ buffer $(\% \mathrm{FeM} w / w)$, increasing Savinase ${ }^{\circledR} 16 \mathrm{~L}$ loading to $3 \%$ augmented $\mathrm{DH}$ by $4.2 \%$ while raising sodium sulphite level to $1.5 \%$ increased $\mathrm{DH}$ by $10.4 \%$ (Table 2). On the other hand, $\mathrm{DH}$ in runs containing $\mathrm{Na}_{2} \mathrm{SO}_{3}$ only (no protease in the mixture) was higher than for those without both sodium sulphite and protease. These results are congruent with the mechanistic concept proposed by multiple authors, whereas a reducing agent (disulphide reductase or chemical reductant), in our case sodium sulphite, enhanced the decomposition of keratin by rupturing the disulphide bridges, thus facilitating the access of proteases to the peptide bonds $[4,5]$. These observations suggest that sodium sulphite level is a limiting factor for the capacity of the protease to hydrolyze FeM. This was supported by the significant interaction $(p<0.05)$ between Savinase ${ }^{\circledR} 16 \mathrm{~L}$ and $\mathrm{Na}_{2} \mathrm{SO}_{3}$ in the analysis of variance for $\mathrm{DH}$ (Table 3). Since the price per ton of sodium sulphite is substantially lower than that of commercial proteases (\$36.60 USD for $250 \mathrm{~g}$ of sodium sulphite versus $\$ 189.00$ USD for $250 \mathrm{~mL}$ of Savinase ${ }^{\circledR}$ 16L [19]), it is highly advantageous to maximize the inclusion of sodium sulphite while minimizing the use of protease. Therefore, adding more than $1.5 \%$ of sodium sulphite ( $\% \mathrm{FeM} w / w)$ to the incubation mixture was considered more efficient and cost-effective.

Furthermore, one mole of sodium sulphite reacts with one mole of cysteine, while the molar mass of sodium sulphite $(126.04 \mathrm{~g} / \mathrm{mol})$ is approximately half that of cystine $(242.32 \mathrm{~g} / \mathrm{mol})$. Given that FeM contains approximately $3.8 \%$ of cysteine (as is basis), adding $2 \%$ of sodium sulphite ( $\% \mathrm{FeM} w / w$ ) to the mixture should theoretically be sufficient to reduce all disulphide bonds. As such, $2 \%$ sodium sulphite $(\% \mathrm{FeM} w / w)$ was considered appropriate for our application. 


\subsubsection{Selecting Digestion Buffer Level}

Robust trends toward the significance of linear $(p=0.0504)$ and quadratic $(p=0.0509)$ effects of digestion buffer level on DH were observed (Table 4). Notably, DH remained at approximately $10 \%$ for all three levels of digestion buffer at $0 \%$ Savinase ${ }^{\circledR} 16 \mathrm{~L}(\% \mathrm{FeM} v / w)$. This demonstrated that increasing the buffer level has a minimal effect on $\mathrm{DH}$ if there is no protease in the incubation mixture to hydrolyze FeM. Significant linear $\left(p=0.005 ; r^{2}=0.10\right)$ and quadratic $\left(p=0.01 ; r^{2}=0.09\right)$ positive relationships between buffer level and DH were observed when all incubations with $0 \%$ Savinase ${ }^{\circledR}$ $16 \mathrm{~L}(\% \mathrm{FeM} v / w)$ were removed from the model.

Significant improvements $(p<0.05)$ in DH were only observed when the digestion buffer level was increased from $200 \%$ to $350 \%$ (\%FeM $w / w)$, which can be seen in Table 4 . This is in agreement with Benjakul and Morrissey [8], who optimized the hydrolysis conditions of Pacific whiting solid wastes using the commercial proteases Alcalase ${ }^{\circledR}$ and Neutrase ${ }^{\circledR}$. They observed no significant change in the solubilization of fish by-products when hydrolyzed with the protease Alcalase ${ }^{\circledR}$ at a digestion buffer level greater than $300 \%$ (\% substrate $w / w$ ). Though significant $(p<0.05)$, the impact on DH of increasing the buffer level from $200 \%$ to $350 \%$ ( $\% \mathrm{FeM} w / w$ ) was minimal, as highlighted by a $4.1 \%$ increase in the DH. Therefore, we have judged that a digestion buffer level of $200 \%$ might be sufficient for our application.

\subsection{Experiment 2}

In Experiment 1, maximum DH was achieved when incubating FeM with $3 \%$ of Savinase ${ }^{\circledR} 16 \mathrm{~L}$ $(\% \mathrm{FeM} v / w), 3 \%$ of sodium sulphite $(\% \mathrm{FeM} w / w)$, and $500 \%$ of digestion buffer (\%FeM $w / w)$. However, data analysis along with literature suggested that reduced inclusion levels of the factors could be used to efficiently hydrolyse FeM. Therefore, we decided to assess the effect of incubating two FeMs of different origins for $24 \mathrm{~h}$ in $200 \%$ of digestion buffer (\%FeM $w / w), 0.5 \%$ of Savinase ${ }^{\circledR} 16 \mathrm{~L}(\% \mathrm{FeM} v / w)$, and $2 \%$ of sodium sulphite $(\% \mathrm{FeM} w / w)$ on their in vitro digestibility.

\subsubsection{Effect of Enzymatic Pretreatment on In Vitro Digestibility}

The pepsin- $\mathrm{HCl}$ digestibility and MSPE results of the two FeMs and their pretreatments are presented in Table 5. Pepsin- $\mathrm{HCl}$ digestibility and MSPE are two in vitro methods commonly used in the animal feed industry to evaluate the protein digestibility of FeM. The Association of American Feed Control Officials (AAFCO) stipulates that no less than $75 \%$ of the protein content in FeM must be digestible in a $0.2 \%$ pepsin- $\mathrm{HCl}$ solution to ensure the adequate processing of the ingredient [20]. However, several studies reported poor correlations between the pepsin- $\mathrm{HCl}$ digestibility assay and the in vivo digestibility of FeM in chickens [21,22]. Therefore, we decided to assess the effect on the pretreatment using MSPE. MSPE is an in vitro procedure developed by Ross et al. [12] to rapidly evaluate the ruminal and intestinal digestibility of protein in cattle.

Table 5. Pepsin- $\mathrm{HCl}$ digestibility and multistep protein evaluation of the two feather meals (FeMs) and their pretreated counterparts.

\begin{tabular}{|c|c|c|c|c|c|c|}
\hline \multirow[b]{2}{*}{ FeM } & \multirow{2}{*}{$\begin{array}{c}\text { Pepsin-HCl Digestibility } \\
(\% \mathrm{~N})\end{array}$} & \multicolumn{5}{|c|}{ Multistep Protein Evaluation } \\
\hline & & $\begin{array}{c}\mathrm{SP} \\
(\% \mathrm{~N})\end{array}$ & $\begin{array}{l}\text { RDP } \\
(\% \mathrm{~N})\end{array}$ & $\begin{array}{l}\text { RUP } \\
(\% \mathrm{~N})\end{array}$ & $\begin{array}{l}\text { IDP } \\
(\% \mathrm{~N})\end{array}$ & $\begin{array}{l}\text { TTDP } \\
(\% \mathrm{~N})\end{array}$ \\
\hline FeM1 & 79.4 & 6.2 & 18.9 & 81.1 & 33.9 & 52.8 \\
\hline PTFeM1 & 92.0 & 49.4 & 61.8 & 38.2 & 17.2 & 79.0 \\
\hline FeM2 & 84.3 & 11.1 & 27.1 & 73.0 & 45.4 & 72.5 \\
\hline PTFeM2 & 90.5 & 47.8 & 61.8 & 38.2 & 21.1 & 82.9 \\
\hline
\end{tabular}

Note. Abbreviations: SP, soluble protein; RDP, rumen degradable protein; RUP, rumen undegradable protein; IDP, intestinal digested protein; TTDP, total tract digested protein. 
The pepsin- $\mathrm{HCl}$ digestibility of protein in both untreated FeMs was above $75 \%$, which conforms to the main protein quality requirement of the industry [20]. The pretreatment increased pepsin- $\mathrm{HCl}$ digestibility from $79.4 \%$ to $92.0 \%$ and $84.3 \%$ to $90.5 \%$ in FeM1 and FeM2, respectively.

The total tract digested protein (TTDP) values measured via the MSPE test in the two untreated FeMs were comparable to those reported by Cotanch et al. [23]. MSPE results showed that the pretreatment increased TTDP values from $52.8 \%$ to $79.0 \%$ and $72.5 \%$ to $82.9 \%$ in FeM1 and FeM2, respectively. The TTDP levels observed in the PTFeMs were greater than those reported by Cotanch et al. [23] for conventional untreated FeMs. Interestingly, the pretreatment enabled the transformation of the two untreated FeMs with very different TTDP levels into two PTFeMs with high and similar TTDP contents. This latter phenomenon suggests that the pretreatment could enable the transformation of FeMs with various digestibility levels into PTFeMs with high and similar digestibility levels.

Results from the MSPE test indicated that both PTFeMs presented higher contents of soluble and rumen degradable protein. However, both FeMs had higher rumen undegradable and intestinal digested protein content compared to their PTFeM counterparts. The latter phenomenon can be explained by the fact that ingredients with low ruminal digestible protein content will have higher rumen undigestible protein content, which enables a higher level of protein to reach the intestinal tract, where it can be digested.

\section{Conclusions}

The present article aimed to describe the experimental procedure performed to develop an enzymatic pretreatment that was demonstrated to improve the amino acid utilization in FeMs fed to rainbow trout [1,2]. Experiment 1 demonstrated that, following a $3 \mathrm{~h}$ incubation period, the optimal combination of $3 \%$ Savinase ${ }^{\circledR} 16 \mathrm{~L}(\% \mathrm{FeM} v / w), 3 \% \mathrm{Na}_{2} \mathrm{SO}_{3}(\% \mathrm{FeM} w / w)$, and $500 \%$ digestion buffer level (\%FeM $w / w)$ solubilized $45 \%$ of nitrogen in FeM. However, the more economically feasible option of incubating FeM with $0.5 \%$ Savinase ${ }^{\circledR} 16 \mathrm{~L}, 2 \% \mathrm{Na}_{2} \mathrm{SO}_{3}$, and $200 \%$ buffer over $24 \mathrm{~h}$ was found to improve the in vitro digestibility of protein in the two FeMs. This pretreatment improved pepsin- $\mathrm{HCl}$ digestibility by $7-16 \%$ and TTGP by $14-50 \%$. Therefore, both in vitro methods enabled a detectable improvement in protein digestibility as a result of our pretreatment. The experimental procedure described in this study enabled the development of an enzymatic pretreatment that (1) improves the nutritional value of protein in FeM fed to rainbow trout and (2) requires lower levels of Savinase ${ }^{\circledR} 16 \mathrm{~L}$, sodium sulphite, and digestion buffer than the optimal levels determined by full factorial design.

Author Contributions: G.P. and D.P.B. conceived and designed the experiments; G.P. and E.H.I. performed the experiments; G.P. and V.O. analyzed the data; D.P.B. contributed reagents/materials/analysis tools; G.P., V.O., and A.K.S. wrote the paper."

Funding: The authors received no specific funding for this work.

Acknowledgments: Thank you to the staff and students of the Fish Nutrition Research Laboratory and of the Monogastric Nutrition Laboratory, both at the University of Guelph.

Conflicts of Interest: The authors declare no conflicts of interest.

\section{References}

1. Pfeuti, G.; Cant, J.P.; Shoveller, A.K.; Bureau, D.P. A novel enzymatic pre-treatment improves amino acid utilization in feather meal fed to rainbow trout (Oncorhynchus mykiss). Aquac. Res. 2019, 50, 1459-1474. [CrossRef]

2. Pfeuti, G.; Longstaffe, J.; Brown, L.S.; Shoveller, A.K.; Taylor, C.M.; Bureau, D.P. Disulphide bonds and cross-linked amino acids may affect amino acid utilization in feather meal fed to rainbow trout (Oncorhynchus mykiss). Aquac. Res. 2019, 50, 2081-2095. [CrossRef]

3. Grazziotin, A.; Pimentel, F.; De Jong, E.; Brandelli, A. Nutritional improvement of feather protein by treatment with microbial keratinase. Anim. Feed Sci. Technol. 2006, 126, 135-144. [CrossRef] 
4. Ramnani, P.; Gupta, R. Keratinases vis-à-vis conventional proteases and feather degradation. World J. Microbiol. Biotechnol. 2007, 23, 1537-1540. [CrossRef]

5. Eslahi, N.; Dadashian, F.; Nejad, N.H. An investigation on keratin extraction from wool and feather waste by enzymatic hydrolysis. Prep. Biochem. Biotechnol. 2013, 43, 624-648. [CrossRef] [PubMed]

6. Gupta, R.; Ramnani, P. Microbial keratinases and their prospective applications: An overview. Appl. Microbiol. Biotechnol. 2006, 70, 21-33. [CrossRef] [PubMed]

7. Mokrejs, P.; Svoboda, P.; Hrncirik, J.; Janacova, D.; Vasek, V. Processing poultry feathers into keratin hydrolysate through alkaline-enzymatic hydrolysis. Waste Manag. Res. 2011, 29, 260-267. [CrossRef] [PubMed]

8. Benjakul, S.; Morrissey, M.T. Protein hydrolysates from Pacific whiting solid wastes. J. Agric. Food Chem. 1997, 45, 3423-3430. [CrossRef]

9. Coll, B.A.; Garcia, R.A.; Marmer, W.N. Diffusion of protease into meat \& bone meal for solubility improvement and potential inactivation of the BSE prion. PLOS ONE 2007, 2, e245.

10. Horwitz, W.; Latimer, G.W. Official Methods of Analysis of AOAC International; AOAC International: Gaithersburg, MD, USA, 2005.

11. Hoyle, N.T.; Merrit, J. Quality of fish protein hydrolysates from herring (Clupea harengus). J. Food Sci. 1994, 59, 76-79. [CrossRef]

12. Ross, D.; Gutierrez-Botero, M.; Van Amburgh, M. Development of an In Vitro Intestinal Digestibility Assay for Ruminant Feeds. Available online: https://www.semanticscholar.org/paper/development-of-an-in-vitrointestinal-digestibility-Ross-Gutierrez-Botero/c184631b49ab95c55b5161d9ad31f5e509268aab (accessed on 15 June 2019).

13. Shahidi, F.; Han, X.-Q.; Synowiecki, J. Production and characteristics of protein hydrolysates from capelin (Mallotus villosus). Food Chem. 1995, 53, 285-293. [CrossRef]

14. Surowka, K.; Fik, M. Studies on the recovery of proteinaceous substances from chicken heads: II-Application of pepsin to the production of protein hydrolysate. J. Sci. Food Agric. 1994, 65, 289-296. [CrossRef]

15. Kristinsson, H.G.; Rasco, B.A. Kinetics of the hydrolysis of Atlantic salmon (Salmo salar) muscle proteins by alkaline proteases and a visceral serine protease mixture. Process Biochem. 2000, 36, 131-139. [CrossRef]

16. Deeslie, W.D.; Cheryan, M. Functional properties of soy protein hydrolyzates from a continuous ultrafiltration reactor. J. Agric. Food Chem. 1988, 36, 26-31. [CrossRef]

17. Normah, I.; Jamilah, B.; Saari, N.; Yaakob, B. Optimization of hydrolysis conditions for the production of threadfin bream (Nemipterus japonicus) hydrolysate by Alcalase. J. Muscle Foods 2005, 16, 87-102. [CrossRef]

18. Guerard, F.; Guimas, L.; Binet, A. Production of tuna waste hydrolysates by a commercial neutral protease preparation. J. Mol. Catal. B Enzymatic 2002, 19, 489-498. [CrossRef]

19. Sigma-Aldrich USA. Available online: https://www.sigmaaldrich.com/united-states.html (accessed on 15 August 2019).

20. AAFCO. 2016 Official Publication; Association of American Feed Control Officials: Champaign, IL, USA, 2016.

21. Han, Y.; Parsons, C. Protein and amino acid quality of feather meals. Poult. Sci. 1991, 70, 812-822. [CrossRef]

22. Papadopoulos, M.C. In vitro and in vivo estimation of protein quality of laboratory treated feather meal. Biol. Wastes 1987, 21, 143-148. [CrossRef]

23. Cotanch, K.; Grant, R.; Dann, H.; Darrah, J.; VanAmburgh, M.; Ross, D. Ruminal and Intestinal Protein and Amino Acid Digestibility of Feather Meal and Feather Meal with Blood Products. Available online: https://www.uspoultry.org/ppfc/docs/FeatherMealCornell.pdf (accessed on 4 October 2019).

(C) 2019 by the authors. Licensee MDPI, Basel, Switzerland. This article is an open access article distributed under the terms and conditions of the Creative Commons Attribution (CC BY) license (http://creativecommons.org/licenses/by/4.0/). 